\title{
FCD Application of Landsat for Monitoring Mangrove in Central Kalimantan
}

\author{
Raden Mas Sukarna and Yuliyanto Syahid
}

Received: 26102015 / Accepted: 0512 2015 / Published online: 15022016

(c) 2015 Faculty of Geography UGM and The Indonesian Geographers Association

\begin{abstract}
A large amount of tropical mangrove forest in Indonesia has been lost due to rapid development in coastal areas, such as, aquaculture, industry, housing, and etc. Assessment of mangrove still mostly used conventional methods. It involves labor intensive, time consuming, high costs and impractical for use in large area. To answer these problems, this study aims to study accuracy and effectiveness of forest canopy density (FCD) model of Landsat for monitoring mangrove changes with large area \pm 2.600 hectares during periods 2002 and 2014 in Central Kalimantan. The result showed that FCD is capable to classified mangrove changes with overall accuracy $89.75 \%$, and known that mangrove changes during approximately 12 years divided into four groups, i.e. deforested areas $11.11 \%$, degraded areas $12.98 \%$, regrowth areas $23.29 \%$ and not change areas $52.62 \%$. Concluded that FCD model is quite accurate and effective used to monitor mangrove changes such as deforestation, degradation and regrowth.
\end{abstract}

Keywords: Landsat Imagery, Forest canopy density, Monitoring, Mangrove

\begin{abstract}
Abstrak Sebagian besar hutan mangrove di Indonesia telah berkurang akibat pembangunan kawasan pesisir seperti tambak, industry, pemukiman dll. Kajian mangrove masih banyak menggunakan metode konvensional. Hal ini tentu membutuhkan banyak tenaga, waktu, dan biaya serta kurang praktis digunakan untuk kawasan hutan yang luas. Untuk menjawab persoalan tersebut, penelitian ini bertujuan untuk mempelajari tingkat ketelitian dan efektivitas model kerapatan kanopi hutan citra Landsat dalam memantau perubahan hutan mangrove dengan luas \pm 2.600 hektar antara tahun 2002-2014 di Kalimantan Tengah. Hasil penelitian menunjukkan bahwa model FCD mampu mengklasifikasikan perubahan hutan mangrove dengan tingkat ketelitian 89,75\%, dan diketahui bahwa perubahan mangrove selama 12 tahun dapat dikelompokkan menjadi empat, yaitu kawasan yang terdeforestasi seluas 11,11\%, kawasan yang terdegradasi seluas 12,98\%, kawasan yang tumbuh kembali seluas 23,29\% dan kawasan yang tidak berubah seluas 52,62\%. Disimpulkan bahwa model FCD cukup teliti dan efektif digunakan untuk memantau perubahan hutan mangrove seperti deforestasi, degradasi dan pertumbuhan.
\end{abstract}

Kata kunci: : Citra landsat, Kerapatan kanopi hutan, Pemantauan, Mangrove

\section{Introduction}

Mangrove forests are extremely important coastal resources, which are vital to our socio-economic development. A vast majority of human population lives in coastal area, and most communities depend on local resources for their livelihood (Kathiresan, 2012). It provides numerous ecosystem services, such as sediment trapping, protection from cyclones and tsunami, habitat for numerous organisms. However, this ecosystem are especially vulnerable to climate and land use change (Murdiyarso et al., 2009). Mangrove forest area in Indonesia estimated 7.8 million hectares (30.7\% in good condition, $27.4 \%$ moderate-destroyed, $41.9 \%$ heavy-destroyed), they are composed of trees (at

Raden Mas Sukarna

Forestry Department, Faculty of Agriculture, Palangka Raya University, Palangka Raya, Central Kalimantan, Indonesia

Email: radenmassukarna@gmail.com

Yulianto Sahid

Watersheds Management Unit of Kahayan-Central Kalimantan, Ministry of Forestry and Environment of Indonesia least 47 species), shrubs (5 species), herbs and grasses (9 species), and parasites (2 species) (Kusmana, 2012).

A large amount of tropical mangrove forest in Indonesia has been lost due to rapid development in coastal areas, such as, aquaculture, ports, industry, plantation development, housing, agriculture and etc. These are among many factors in causing the loss of valuable tropical mangrove forest. FAO (2007) reported that between 1980 and 2005 approximately 25\% of the region's mangroves in Southeast Asia's tropical forests were converted to other land uses. Change will include land-use alterations within both the estuary and its watershed, together with projections of climate change in tropical coastal areas (Twilley, et al., 1996). These rapid changes should be studied using a simple method and low cost. Meanwhile, monitoring of forest alterations still mostly used conventional methods, where forest biophysical parameters are collected by field observation. It involves labor intensive, time consuming field surveys, entails high costs and impractical for use in large spatial extents (Mahboob and Iqbal, 2012; Mon 
et al., 2012; Erfanifard and Khodaee, 2013, Wannasiri et al., 2013). However, improvement of remote sensing science and technology offers an alternative methods for forest mapping and monitoring.

In 1990s, Japan Overseas Forestry Consultants Association (JOFCA) and International Tropical Timber Organization (ITTO) have been successfully developed Forest Canopy Density (FCD) model to classify and monitor the tropical forest fragmentation in Asia such as India, Myanmar, Malaysia and Indonesia (Rikimaru, 1996). Thus, FCD acts as one of the important parameters in the planning and implementation of forest rehabilitation programs (Rikimaru et al. 2002). Several studies have been used FCD model to measure and monitor forest canopy density. Biradar et al. (2005) explained that FCD mapping is one of the tools used to identify such canopy openings and most useful parameter to consider in the planning and implementation of afforestation and reforestation program in Southern part of the Dehradun district of Uttaranchal state. Joshi et al. (2006) compared FCD method with another methods. The result showed that FCD more accurate than multi linier regression and maximum likelihood classification. Panta and Kim (2006) have investigated the spatial-temporal dynamic alterations of FCD across with site associated factors such as biophysical, physical and human interferences in tropical region of Nepal from 1988 to 2001 using Landsat TM and ETM+.

Deka et al. (2012) found the ability of FCD model to detect the temporal change of tropical deforestation in North East India with overall accuracy of $84.0 \%$ and kappa coefficient of 0.77 . Mon et al. (2012) revealed that FCD Mapper can be applied to monitor tropical mixed deciduous vegetation over time at lower cost than alternative methods in Myanmar. Banerjee et al. (2014) used Landsat TM image for detecting in an old growth forest of North forest division of India using FCD, and found the overall accuracy for classified TM image is $80 \%$ and Kappa Coefficient is 0.74. Sukarna (2014) used FCD model to classify floristic diversity of peat swamp forest in Central Kalimantan Indonesia. It has been known that dense forest of FCD associated with high floristic diversity, and low forest of FCD associated with low floristic diversity. Another study also used forest cover as a parameters to determine, classify and monitor forest condition using remote sensing such as which have been reported by Forkuo and and Frimpong (2012), Giree et al., (2013), Tian et al.,(2014), and Tran et al.,(2015). However, the analyses dynamic changes of FCD integration with inside and outside factors is still needed to obtain the best research. Therefore, in this study, we tried to integrate the various forest condition that could have possibly influence on dynamic changes of FCD. Based on implementation and application of FCD model widely, the main objective of this research is to study degree of accuracy and effectiveness of FCD model Landsat data for monitoring mangrove changes as well as its associated factors such as forest density and composition.

\section{The Methods}

Study Area

A part of secondary mangrove forest of Tanjung Keluang Natural Tourism Park in West Kotawaringin District, Central Kalimantan, Indonesia has been selected for studying with large areas approximately 2,600 hectares (Figure 1). This area is within latitude of $111039^{\prime}$ to 111043 'S and longitude of 20 52'to 2058 'E. The climate of study area is wet and is characterized by high rainfall and high relative humidity. Topography in the area is generally flat with slopes ranging from $0-10 \%$ and physiographic of the area constitutes plains with the elevation varies between $0 \mathrm{~m}$ to $5 \mathrm{~m}$ above mean sea level. Soil conditions are generally the peat swamp, sand on the beach and mud on the bay.

Climatic conditions in this area affected by dry and rainy seasons. The dry season occurs in June to September, while the rainy season between October to May. Annual rainfall $32.505 \mathrm{~mm}$, with maximum temperature $31.1^{\circ} \mathrm{C}$ and a minimum temperature about $22{ }^{\circ} \mathrm{C}$, as well as relative humidity $87.08 \%$. The main forests of the study area were of Rizhophora apiculata, Bruguiera spp, Lumnitzera littorea, Xylocarpus spp, and etc. Besides trees, species of shrubs, herbs and grass are also growing in this area.



Figure 1. The location of study area in Central Kalimantan

Data Used and Image Pre-processing

The U.S. Geological Survey (http://earthexplorer. usgs.gov/) is primary source of rectified Landsat 7 ETM+ August 14th, 2002 and Landsat 8 OLI and TIRS August, 23th 2014, path-row 120-062 were used for processing of mangrove forest changes. The first in the pre-processing step was to mask all cloud, cloud shadow and water pixel from its scenes. It has been found that imageries of 2002 and 2014 are cloud free datasets. Clouds have a higher irradiance value than ground data. Moreover, the amount of irradiance varies depending on whether the clouds are white, gray, black or combinations of different shades. These factors 
adversely influence statistical treatment and analysis of imagery data. These problems can be minimized by creating a cloud shadow mask, using a histogram based on data derived from TM band 1, 2, and 3. Water bodies create similar problems. Since water absorbs near infrared, water bodies should also be masked using a histogram of near infrared (NIR). Masking of cloud, cloud shadow or water can be performed either on the basis of histogram of the individual band. The next step was the image geometric correction. Since the scenes were taken in different dates, so there is a marginal difference in the geometric accuracy. Dataset of 2002 is being resampled to 2014 through Image to image registration which are co-registered in Geography WGS-84 coordinate system using nearestneighborhood algorithm. After that all Landsat bands (except thermal band) were normalized using linear transformation.

\section{Forest Canopy Density Modelling}

FCD model is based on the growth phenomenon of forests. Consequently, it also becomes possible to monitor transformation of forest conditions over time such as the progress of forestry activities (Rikimaru, 2003). The digital images processing have been done using PC based of Semi-Expert Remote Sensing System for Forest Canopy Density Mapping (FCD-Mapper Version 2) on Windows 7. FCD model involves biospectral phenomenon modelling and analysis utilizing data derived from four indices, namely, Advance Vegetation Index (AVI), Bare Soil Index (BI), Shadow Index (SI) and Thermal Index (TI) as explained bellow (Rikimaru, 1996; Rikimaru, 2003). Then, explained when assessing the vegetation status of forests, the new methods first examine the characteristics of chlorophyll-a using AVI. It has been more sensitive to forest density and physiognomic vegetation classes, and reacts sensitively for the vegetation quantity compared with Normalized Difference Vegetation Index (NDVI). Shadow and thermal index increases as the forest density and vegetation quantity increases respectively. AVI has been calculated using equation 1 .

$$
\text { 1) } \mathrm{AVI}=\{(\mathrm{B} 4+1) \times(256-\mathrm{B} 3) \times(\mathrm{B} 43)\}^{\wedge}(1 / 3)
$$

where, B3 is red band, B4 is near infrared band response of Landsat.

The value of the vegetation index is not so reliable in situations where the vegetation covers less than half of the area. For more reliable estimation of the vegetation status, the new methods include a bare soil index (BI) which is formulated with medium infrared information. The underlying logic of this approach is based on the high reciprocity between bare soil status and vegetation status. By combining both vegetation and bare soil indices in the analysis, one may assess the status of forest lands on a continuum ranging from high vegetation conditions to exposed soil conditions. BI has been calculated using equation 2 .

$$
\text { 2) } \begin{aligned}
\mathrm{BI}= & \{(\mathrm{B} 5+\mathrm{B} 3)-((\mathrm{B} 4+\mathrm{B} 1)) /((\mathrm{B} 5+\mathrm{B} 3))+(\mathrm{B} 4+\mathrm{B} 1)\} \\
& \mathrm{x} 100+100
\end{aligned}
$$

where, B3 is red band, B4 is near infrared band, B5 is middle infrared response of Landsat.

One unique characteristic of a forest is its three dimensional structure to extract information on the forest structure from remote sensing data. The new methods examine the characteristics of shadow by utilizing (a) spectral information on the forest shadow itself and (b) thermal information on the forest influenced by shadow. The shadow index (SI) is formulated through extraction of the low radiance of visible bands. SI has been calculated using equation 3 .

$$
\text { 3) } \mathrm{SI}=\{(256-\mathrm{B} 1) \times(256-\mathrm{B} 2) \times(256-\mathrm{B} 3)\} \wedge(1 / 3)
$$

where, B1 is blue band (B), B2 is green band, B3 is red band response of Landsat.

Two factors account for the relatively cool temperature inside a forest. One is the shielding effect of the forest canopy which blocks and absorbs energy from the sun. The other is evaporation from the leaf surface which mitigates warming. Formulation of the thermal index is based on these phenomena. Formulation of the Thermal Index (TI) is based on shielding effect of the forest canopy which blocks and absorbs energy from the sun and evaporation from the leaf surface which mitigates warming. TI has been calculated using equation 4 .

\section{4) $\mathrm{TI} \rightarrow \mathrm{L}=[\mathrm{L} \cdot \mathrm{min}+(\mathrm{L} \cdot \max -\mathrm{L} \cdot \min )] / 255 \times \mathrm{Q}$}

where L: value of radiance in thermal infrared, Q: digital record $\mathrm{L}$ min $=0.1238$ watts/meter square, $\mathrm{L}$ $\max =1.500$ watts/meter square

By combining VI, SI and SI in the spectral analysis, we also may assess the status of forest clusters (FC) which has been calculated using equation 5 .

$$
\text { 5) } \mathrm{FC}=(\mathrm{VI} \times \mathrm{SI} \times(256-\mathrm{BI})+1)^{\wedge}(1 / 3)
$$

Integration of vegetation density (VD) and scaled shadow index (SSI) means transformation for forest canopy density (FCD) value. Both parameter has dimension and has percentage scale unit of density. $\mathrm{VD}$ is the procedure to synthesize VI and BI by using principal component analysis. Since, VI and BI have high negative correlation. Then it is scaled between zero to hundred percent. The SSI was developed in order to integrate VI values and SI values. In areas where the SSI value is zero, this corresponds with forests that have the lowest shadow value (i.e. $0 \%$ ). In areas were the SSI value is 100 , this corresponds with forests that have the highest possible shadow value (i.e. 100\%). SSI is obtained by linear transformation of SI. With 
development of the SSI one can now clearly differentiate between vegetation in the canopy and vegetation on the ground. This constitutes one of the major advantages of the new methods. It significantly improves the capability to provide more accurate results from data analysis than was possible in the past. Both VD and SSI parameter has no dimension and has percentage scale unit of density. It is possible to synthesize both indices safely by means of corresponding scale and units of each. FCD has been calculated using equation 6 .

\section{6) $\mathrm{FCD}=(\mathrm{VD} \times \mathrm{SSI}+1)^{\wedge}(1 / 2)-1$}

Ground Survey and Data Analysis

Forest structure and composition have been recorded from 77 sample plots which measured using line plots systematic sampling in 2014. Further, the data were analyzed using formulates such as Important Value Index, Diversity Index, and Dispersion Index.

\section{Result and Discussion}

\section{Determination of Vegetation Density}

Statistics analysis showed that correlation index (r) through principle component analysis (PCA) between AVI and BI of Landsat 2002 and Landsat 2014 is -0.794 and -0.771 respectively. It showed that combining AVI and BI was significant used to determine and identify green vegetation density or green biomass but was not effectively used to determine heterogenous forest canopy structure. We have been examined that if vegetation canopy was too dense due to vegetation index would be saturated and consequently resulting in error estimation especially to predicted heterogeneous forest canopy structure. Micheal et al., (2004) explained that estimation error through of forest structure density is not sufficient to assess the variability of the land surface that caused by the effect of lower layers of vegetation, background reflection, image restoration, a time difference of field measurements and satellite data acquisition as well as the spatial resolution.

To avoid the problem we have developed by entering value of SI and TI (Rikimaru and Miyatake, 1997). SI was very dependent on total high vegetation such as trees with significant canopy shadows, whereas it would cause reduction of TI. It means that if value of vegetation canopy shadow is high, value of temperature is low. However, the results indicated that main factor to distinguish forest cluster was SSI. We have been examined, although VD was high (91-100\%), whereas SSI was low (0 - 20\%), then FCD value was also low $(0-20 \%)$, and indicated that the area was generally dominated by very dense grass and bush land. On the other hand, if SSI was high $(>80 \%)$ and VD was low $(<30 \%)$, then FCD was ranged from $40 \%$ to $60 \%$, and indicated that the area was generally dominated by medium forest.

Scatter diagram analysis (Table 1) showed that the relationship between SI and TI 2002 to 2014 are negative correlation with value -0.583 and -0.494 respectively. It was clear that the higher of mangrove canopy shadow would decrease the value of the temperature. Otherwise the relationship between $\mathrm{BI}$ and $\mathrm{TI}$ are positive correlation with value 0.799 and 0.741 respectively. This mean that the higher value of BI would be followed by the higher value of TI. Through the integration between the VI, BI, TI and SI values may be determined forest cluster (FC) which is able to distinguish between vegetation on the canopy and vegetation on the ground.

Forest Cluster analysis of Landsat 7 ETM 2002 and Landsat 8 OLI-TIRS 2014 (Table 2) showed that clusters of open forest have an average value of VI and SI are relatively low, and otherwise have an average value of $\mathrm{BI}$ and value of TI are high. Likewise in contrast to the dense forest areas have an average value of VI and SI are high, and the average value of BI and TI are low. Based on the value of the forest cluster, then the mangrove forests can be grouped into six zones forest cluster.

Determination of forest clusters based on formula 5 needs to be improved using a combination of VI and $\mathrm{BI}$ to find vegetation density model (VDM) and conducted linear transformation analysis of SI to get SSI. Integration VDM and SSI produces FCD class in 2002 and 2014 which representative and effective to clasified forest structure. Hence, FCD class during periods 2002 to 2014 are descripted in percentages from $0 \%, 1-10 \%, 11-20 \%, 21-30 \%, 31-40 \%, 41-50 \%, 51-60 \%$,

Table 1. Correlation Index of AVI, BI, SI and TI

\begin{tabular}{lrrrrrr}
\hline \multirow{2}{*}{ Combination } & \multicolumn{3}{c}{ Landsat 7 ETM+2002 } & \multicolumn{2}{c}{ Landsat 8 OLI-TIRS 2014 } \\
& Correlation & \multicolumn{1}{c}{ Slope } & Intercept & Correlation & \multicolumn{1}{l}{ Slope } & Intersect \\
\hline AVI-BI & -0.558 & -0.254 & 134.277 & -0.494 & -0.134 & 123.889 \\
SI-TI & -0.676 & -0.374 & 180.84 & -0.534 & 0.110 & 190.300 \\
AVI-SI & 0.376 & 0.385 & 110.549 & 0.273 & 0.277 & 123.661 \\
BI-SI & -0.569 & -0.623 & 210.373 & -0.575 & -0.829 & 231.282 \\
BI-TI & 0.799 & 1.138 & -20.336 & 0.741 & 0.618 & 95.639 \\
\hline
\end{tabular}


Table 2. Mangrove Cluster Based on AVI, BI, SI and TI

\begin{tabular}{crrrrr}
\hline No. FC & FC 2002 & AVI & BI & SI & TI \\
\hline 1 & 158 & 185.5 & 111.5 & 148.8 & 208.0 \\
2 & 163 & 195.2 & 113.0 & 154.5 & 183.3 \\
3 & 165 & 172.3 & 113.6 & 181.4 & 195.4 \\
4 & 175 & 188.0 & 104.9 & 187.8 & 178.2 \\
5 & 178 & 200.8 & 104.7 & 184.8 & 156.4 \\
6 & 186 & 217.3 & 98 & 187.8 & 178.1 \\
\hline No. FC & FC 2014 & AVI & BI & SI & TI \\
\hline 1 & 142 & 178.9 & 122.0 & 121.7 & 192.2 \\
2 & 147 & 150.0 & 121.3 & 158.1 & 178.1 \\
3 & 159 & 198.6 & 115.1 & 143.6 & 176.6 \\
4 & 162 & 171.2 & 111.1 & 173.9 & 162.8 \\
5 & 174 & 204.0 & 107.4 & 173.7 & 161.3 \\
6 & 183 & 231.2 & 109.3 & 180.2 & 157.7 \\
\hline
\end{tabular}

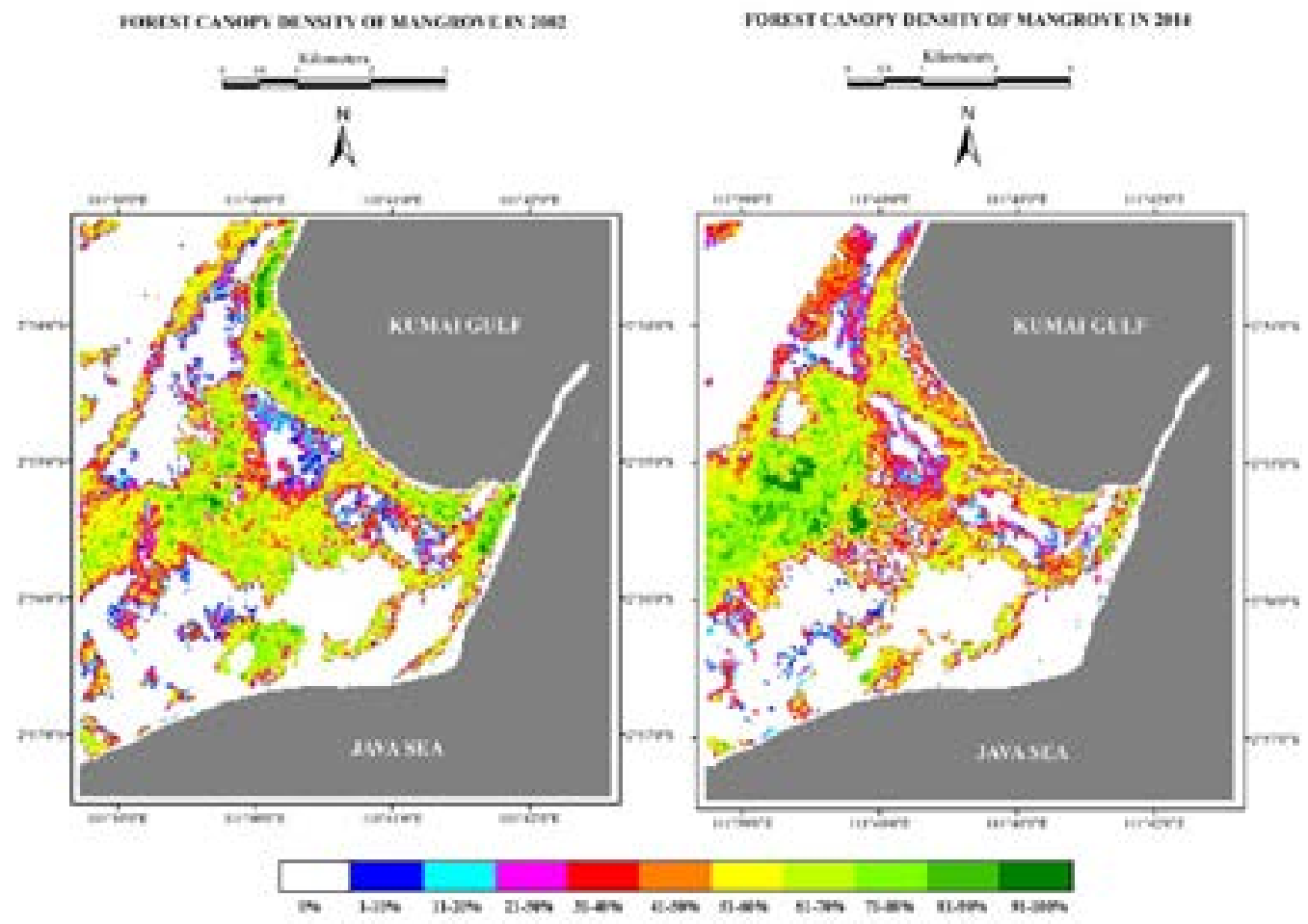

Figure 2. Map of forest canopy density of landsat 7 ETM+ 2002 and landsat 8 OLI-TIRS 2014

$61-70 \%, 71-80 \%, 81-90 \%$ to $91-100 \%$ (Figure 2).

These classification techniques should be compared on extended areas, on different vegetation structures, on different species composition, bare soil and local temperature. Classification of satellite data using FCD model based on biophysical approach has also used many researcher and has given different results (Panta and Kim, 2006). It has also reported that most of the results from previous research have claimed high correlation between the reflectance and field measurement of FCD. Deka et al., (2012) reported that the vegetation indices reduce the effects of bias and assist in the extraction of the significant features of a specific ground object.

Mangrove Changes During Periods 2002 to 2014

Based on ground truth information for different forest structure, the percentage of FCD classes were 




Figure 3. Map of mangrove forest classification

Table 3. Land Cover Changes of Mangrove Forest Periods 2002 to 2014 in Study Area

\begin{tabular}{cllrrr}
\hline No. & FCD Class & Mangrove Cover & $\begin{array}{c}\text { Area in 2002 } \\
\text { (Hectare) }\end{array}$ & \multicolumn{1}{c}{$\begin{array}{c}\text { Area in 2014 } \\
\text { (Hectare) }\end{array}$} & $\begin{array}{c}\text { Changes of Area } \\
\text { (Hectare) }\end{array}$ \\
\hline 1 & $0 \%$ & Non Forest & $1,353.69$ & $1,381.77$ & 28.08 \\
2 & $1-20 \%$ & Very Low Forest & 171.09 & 112.05 & $(59.04)$ \\
3 & $21-40 \%$ & Low Forest & 269.28 & 310.50 & 41.22 \\
4 & $41-60 \%$ & Medium Forest & 516.87 & 548.37 & 31.50 \\
5 & $61-80 \%$ & Dense Forest & 430.29 & 369.99 & $(60.30)$ \\
6 & $81-100 \%$ & Very Dense Forest & 51.21 & 69.75 & 18.54 \\
\multicolumn{2}{c}{ Total Area $(\mathrm{Ha})$} & & $2,792.43$ & $2,792.43$ & 0.00 \\
\hline
\end{tabular}

Source: FCD analysis of Landsat 2002, Landsat 2014 and ground survey in 2014

Table 4. Changes in Each Mangrove Cover During Periods 2002 to 2014

\begin{tabular}{|c|c|c|c|c|c|c|c|}
\hline \multirow{2}{*}{$\begin{array}{c}\text { Mangrove Classes in } \\
2014 \text { (Hectare) }\end{array}$} & \multicolumn{7}{|c|}{ Mangrove Classes in 2002 (Hectare) } \\
\hline & $\begin{array}{l}\text { Non } \\
\text { Forest }\end{array}$ & $\begin{array}{l}\text { Very Low } \\
\text { Forest }\end{array}$ & $\begin{array}{l}\text { Low } \\
\text { Forest }\end{array}$ & $\begin{array}{l}\text { Medium } \\
\text { Forest }\end{array}$ & $\begin{array}{l}\text { Dense } \\
\text { Forest }\end{array}$ & $\begin{array}{l}\text { Very Dense } \\
\text { Forest }\end{array}$ & $\begin{array}{l}\text { Class } \\
\text { Total }\end{array}$ \\
\hline Non Forest & $1,076.13$ & 65.70 & 73.08 & 98.73 & & 63.27 & 4.86 \\
\hline Very Low Forest & 50.76 & 16.56 & 15.75 & 17.82 & 10.35 & 0.81 & 112.05 \\
\hline Low Forest & 83.25 & 39.06 & 57.06 & 80.55 & 46.89 & 3.69 & 310.50 \\
\hline Medium Forest & 80.28 & 34.29 & 83.16 & 179.73 & 152.46 & 18.45 & 528.37 \\
\hline Dense Forest & 47.91 & 11.61 & 33.75 & 120.15 & 136.71 & 20.16 & 369.99 \\
\hline Very Dense Forest & 15.66 & 3.87 & 6.48 & 19.89 & 20.61 & 3.24 & 69.75 \\
\hline Class Total & $1,353.69$ & 171.09 & 269.28 & 516.87 & 430.29 & 51.21 & $2,792.43$ \\
\hline Class Changes & 277.56 & 154.53 & 212.22 & 337.14 & 293.58 & 47.97 & $1,323.00$ \\
\hline
\end{tabular}

Source: Analysis of Landsat 2002, Landsat 2014 and ground survey in 2014 
areas between the periods.

Meanwhile, in area study has also found that the rate of species diversity index $\left(\mathrm{H}^{\prime}\right)$ for all standing is currently low (Figure 5). It has been indicated that growing of mangrove diversity in this area is toward climax. We have been observed that decreasing of forest density followed by decreasing diversity of poles, whereas also followed by increasing diversity of seedlings. The fact that either decreasing or increasing of poles and seedlings was significant to influence variant of FCD. Species composition in this area as a whole is composed by 8 species, 6 genera and 5 family which dominated by Rhizophora apiculata, Brugueira gymnorrhiza, Brugueira farviflora, Lumnitzera littorea and Xylocarpus granatum respectively.

Mangrove zoning in this area divided into two regions, namely the outer bordering the sea is dominated by Rhizophora apiculata, and central area to the inland zone dominated by Brugueira gymnorrhiza. The difference due to the influence of salinity and soil properties (Kushartono, 2009). Field observations indicate that the salinity level of water in the outer area or adjacent to the sea tends to be higher than inland areas. These differences that caused the formation of mangrove zoning from the seaside to the inland area. Biodiversity components of tropical estuaries can refer to the diversity of species, life histories, habitats and links in food webs (Twilley et al., 1996). Then explained that geomorphological and ecological not only can be used to integrate the different scales of environment factors that control the attributes of forest structure, but they may also control species richness (Smith, 1992).

Furthermore, the result also found that dispersion index average of seedlings 0.49 , saplings 0.53 , poles 0.31 and trees 0.39 , respectively. It has explained that distribution pattern of mangrove for all stand strata is categorized into clustered distribution pattern. It is a common pattern distribution formed as the pattern of other vegetation, similarly such as reported by Guntur (2012) at Togean Island National Park, South Sulawesi Province and also reported by Wiharja (2013) at Langkat District, North Sumatra Province. Fluctuating of mangrove cluster result in diver spatial and temporal distribution pattern of species as well as site factors.

We predicted that the site factors of a region determined by many the hydrologic and chemical condition of soil that control the species distribution pattern of mangrove. In addition, tidal flooding frequency can also influence the species pattern distribution. Lignon et al., (2011) reported that changes in hydrology and water quality are important indicators, as change in these parameters can influence colonization, succession and zonation and in time can cause increased tree mortality and consequent alteration of the structural characteristics of the mangrove stand. Twilley et al. (1996) also reported that temperature is the basic climatic factor governing limits of mangrove distribution. The responses of mangrove forest to decreasing temperature are reductions in species richness, forest structure, forest height and biomas.

\section{Conclusion}

Assessment of the forest canopy density through satellite is a prerequisite for various planning activities of forest changes especially at a medium or large area level. Usage FCD model from Landsat TM and OLITIRS was accurate and capable to identify forest canopy density and its attributes effectively and less information of ground validation in this study with overall accuracy $89.75 \%$ and kappa coefficient 0.85 . However, additional research comparing the precision of FCD model to other alternatives is still needed regarding for better methods. Certainly, the potential of higher resolution imagery mapping should be used further to support FCD model. Based upon FCD analysis we found that alterations of mangrove canopy density was a marked both declining

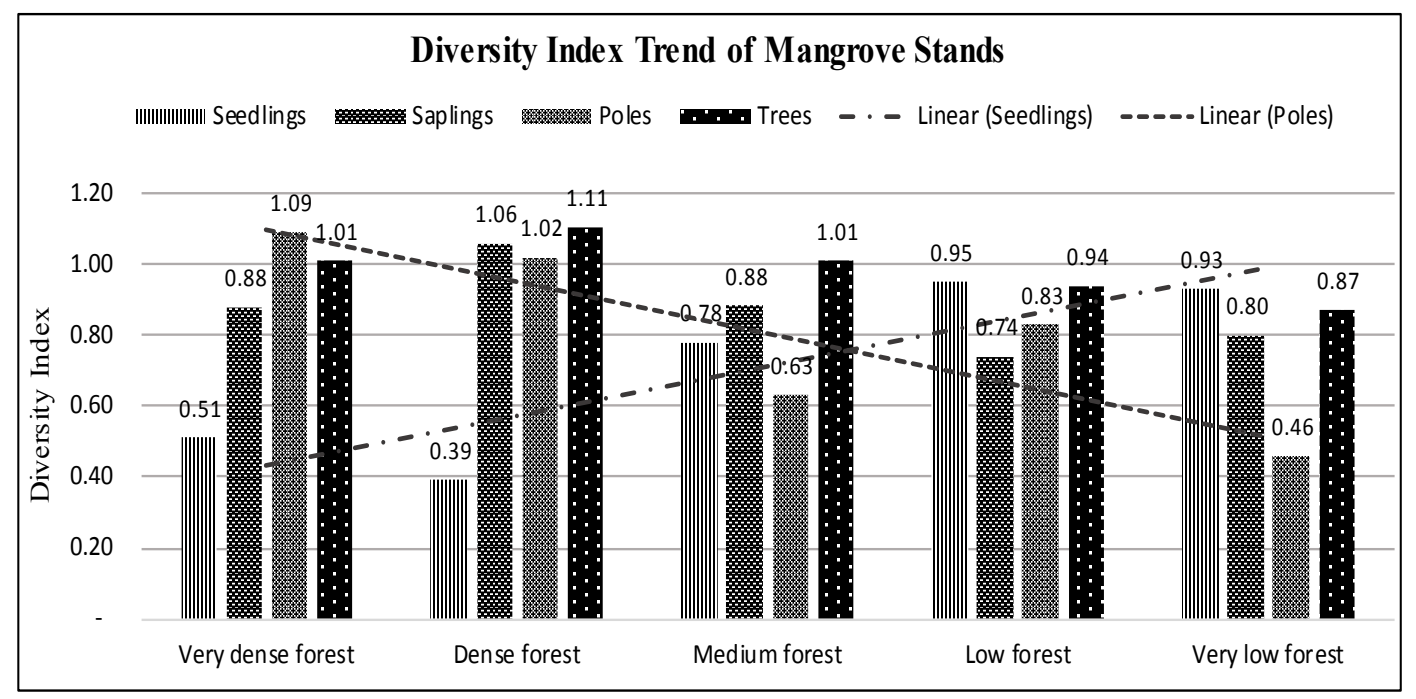

Figure 5. Diversity index trend of mangrove stands (seedlings, saplings, poles and trees) in 2014 based on FCD classification 
in dense forest class whereas an increasing in medium forest and low forest areas during 2002 to 2014. The fact that, the changes of canopy density related with inside factors such as structure, composition, diversity and distribution pattern. These facts illustrate that mangrove in this area is currently decreasing in term of its species diversity. Therefore, we recommended that comprehensive study should be considered to manage mangrove changes sustainable. In this analysis we didn't cover all the factors that have possibilities to affect the forest canopy alteration, it should be analyzed in a comprehensive way. Therefore, to explain mangrove environmental changes through FCD is complex without detail analysis and understanding of the other factors, but FCD model could be affected enough to analyze particularly for middle resolution imagery. Importantly, FCD could be affected by forest biometric such as stand density and biodiversity characteristics of stand.

\section{References}

Azizia, Z., Najafia, A., Sohrabia, H. (2008), Forest canopy density estimating, using satellite images. The International Archives of the Photogrammetry, Remote Sensing and Spatial Information Sciences. 37(8) 1127-1130.

Banerjee, K., Panda S., Bandyopadhyay, J., Jain, M.K. (2014), Forest canopy density mapping using advance geospatial technique. International Journal of Innovative Science, Engineering \& Technology. 1(7) 358-363.

Biradar, C.M., Saran, S., Raju, P. L. N., Roy, P.S. (2005), Forest canopy density stratification: how relevant is biophysical spectral response modelling approach? Geocarto International Journal. 20(1) 1-7.

Deka, J., Tripathi, O.K., Khan, M.L. (2012), Implementation of forest canopy density model to monitor tropical deforestation. Journal of the Indian Society of Remote Sensing, DOI 10.1007/ s12524-0224-5.

Erfanifard, Y. and Khodaee, Z. (2013), Canopy density mapping on ultracam-d aerial imagery in Zagros woodlands, Iran. Remote Sensing and Spatial Information Sciences. 40(1) 159-164.

Food and Agriculture Organization of the United Nations. (2007), the world's mangroves 1980-2005. FAO forestry report 153, Rome.

Forkuo, E.K., and Frimpong, A. (2012), Analysis of forest cover change detection. International Journal of Remote Sensing Applications. 2(4) 82-92.

Giree N., Stehman S V., Potapov, P. and Hansen M. C. (2013), A sample-based forest monitoring strategy using Landsat, AVHRR and MODIS data to estimate gross forest cover loss in Malaysia between 1990 and 2005. Remote Sens. 5 1842-1855.

Giri, C. and Muhlhausen, J. (2008), Mangrove Forest Distributions and Dynamics in Madagascar (1975-
2005). Sensors. 8 2104-2117.

Guntur, M. (2012), Community structure of mangrove in Togean Island National Park. (Unpublished thesis). Universitas Gadjah Mada, Indonesia.

Joshi, C., Leeuw, J.D., Skidmore, A.K., van Duren, I.C., van Oosten, H. (2006), Remotely sensed estimation of forest canopy density: a comparison of the performance of four methods. International Journal of Applied Earth Observation and Geo-information. 8 84-95.

Kathiresan, K. (2012), Importance of Mangrove Ecosystem. International Journal of Marine Science. 2 (10) $70-89$.

Kushartono, E.W. (2009), some aspects of biophysicalchemical of soil in Rembang sub district. Jurnal Ilmu Kelautan. 14(2) 76-83.

Kusmana, C. (2012), Management of mangrove ecosystem in Indonesia. Paper in workshop on mangrove re-plantation and coastal ecosystem rehabilitation, held at Universitas Gadjah Mada, Indonesia, February 7, 2012.

Lignon, M.C., Coelho Jr. C., Almeida, R., Menghini, R.P., Novelli, Y.S., Cintrón,G., and Guebas, F.D. (2011), Characterisation of mangrove forest types in view of conservation and management: a review of mangals at the Cananéia region, São Paulo State, Brazil. Journal of Coastal Research. 64 349-353.

Mahboob, J. and Iqbal, F. (2012), Forest crown closure assessment using multispectral satellite imagery. African Journal of Agricultural Research. 7(36) 5033-5042.

Mon, M. S., Mizoue. N., Htun N.Z., Kajisa, T and Yoshida, S. (2012), Estimating forest canopy density of tropical mixed deciduous vegetation using Landsat data: a comparison of three classification approaches. International Journal of Remote Sensing. 33(4) 1042-1057.

Murdiyarso, D., Donato, D., Kauffman, J.B., Kurnianto, S., Stidham, M., Kanninen, M. (2009), Carbon storage in mangrove and peatland ecosystems, a preliminary account from plots in Indonesia. Working paper 48, Center for International Forestry Research (CIFOR) Bogor, Indonesia, p 35.

Oyebade, B.A., Emerhi, E.A, Ekeke, B.A. (2010), Quantitative review and distribution status of mangrove forest species in West Africa. International Multi-Disciplinary Journal. 4(2) 8089.

Pannombalam, K., Chokkalingam, L., Subramaniami, V., Ponniah, J.M. (2012), Mangrove distribution and morphology changes in the Mullipalam Creek, southestern coast of India. International Journal of Conservation Science. 3(1) 51-60.

Panta, M. and Kim, K. (2006), Spatio-temporal dynamic alteration of forest canopy density based on site associated factors: view from tropical forest of Nepal. Korean Journal of Remote Sensing. 22(5) $1-11$. 
Ram, A.T. and Shaji, C.S. (2013), Diversity and distribution of mangroves in Kumbalam island of Kerala, India. IOSR Journal of Environmental Science. 4(4) 18-26.

Rikimaru, A. (1996), Landsat TM data processing guide for forest canopy density mapping and monitoring model. ITTO workshop on utilization of remote sensing in site assessment and planting of logged-over forest, held at Bangkok, July 30 - August 1, 1996.

Rikimaru, A. (2003), Consept of FCD mapping model and semi expert system. FCD Mapper Ver. 2. User Guide, ITTO and JOFCA. pp $32-42$.

Rikimaru, A., Roy, P.S., Miyatake, S. (2002), Tropical forest cover density mapping. Tropical Ecology. 43(1) 39-47.

Smith, T.J. (1992). Forest structure. In Robertson, A.I. and Alongi, D.M. (Eds); Tropical mangrove forest ecosystem. American Geophysical Union, Washington DC, pp: 101-136.

Sukarna, R.M. (2014), Study of landscape ecology floristic of peat swamp forest based on remote sensing imagery in central Kalimantan, Indonesia. Jurnal Hutan Tropis. 2(1) 52-59.
Tian, Y., Yin, K., Lu, D., Hua, L., Zhao, Q., and Wen, M. (2014), Examining land use and land cover spatiotemporal change and driving forces in Beijing from 1978 to 2010. Remote Sens. 6 10593-10611.

Twilley, R.R., Snedaker, S.C., Arancibia, A.Y., and Medina, E. (1996), Biodiversity and ecosystem processes in tropical estuaries: perspective of mangrove ecosystem (chapter 13) in Mooney, H.A., Cushman, J.H., Medina, E., Sala, O.E., Schuleze, E.D. (Eds): Fungsional roles of biodiversity: a global perspective. John Wiley and Sons Ltd, pp: 327-370.

Tran, H., Tran, T., and Kervyn, M. (2015), Dynamics of land cover/land use changes in the Mekong delta, 1973-2011: a remote sensing analysis of the Tran Van Thoi district, Ca Mau Province, Vietnam. Remote Sens. 7 2899-2925.

Wannasiri, W., Nagai, M., Honda, K., Santitamnont, P. and Miphokasap, P. (2013). Extraction of mangrove biophysical parameters using airborne LiDAR. Remote Sens. 5 1787-1808.

Wiharja, P. (2013), Community structure of mangrove in Langkat District North Sumatera. (Unpublished thesis). Universitas Gadjah Mada, Indonesia. 